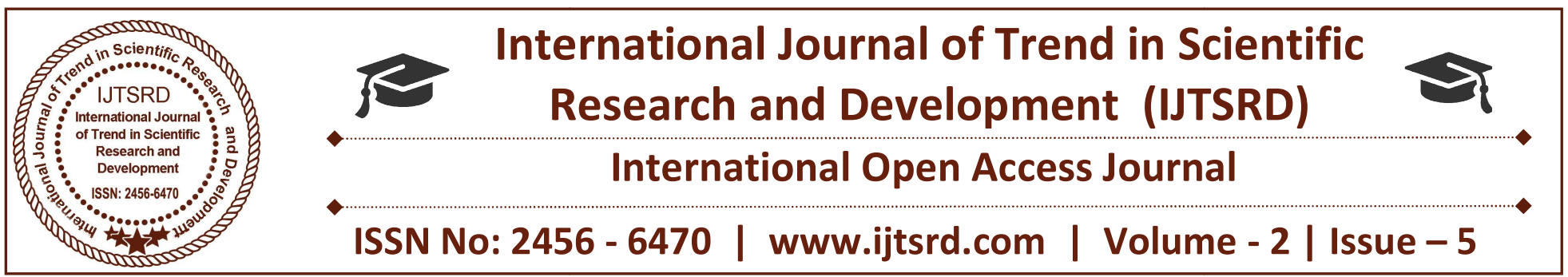

\title{
An Impact of GST on Textile Industry in India
}

\author{
Urvashi Gupta \\ B.A., LL.B (Hons), Indore Institute of Law \\ Indore, Madhya Pradesh, India
}

\section{ABSTRACT}

this paper is an investigation of what the effect of GST (Goods and Services Tax) will be on textile area. GST isn't just an expense change yet a business change as it will affect all elements of an association, for example, fund, item evaluating, store network, data innovation, contracts, ads and so forth. Therefore, it is basic that all these utilitarian groups ought to know about the GST. Be that as it may, the basic inquiry is what should these colleagues perused/allude for GST? There are blended reaction, inexplicit contentions and assessments among the Manufactures, dealers and society about the Goods and Services Tax (GST) to be actualized by Government of India. GST is a extensive, circuitous, multi-arrange, goal based expense that will be imposed on each esteem expansion. The products and ventures assess (GST) is gone for making a solitary bound together market that will straightforwardly influences all areas and segments of our economy. This is the greatest change proposed in the assessment administration of our nation after freedom. It is something that every one of us must comprehend as it will influence our lives in an extremely noteworthy way. France was the primary nation to present GST in 1954. Around the world, Very nearly 150 nations have presented GST in either frame since now. India has picked the Canadian model of double GST. Presentation of GST could considerably affect material industry. It is one of key area in Indian economy with an immediate linkage to the general development of Indian also, worldwide economy. Material assumes a noteworthy part in the Indian economy India's textile market estimate measure in (USD billion). It contributes 14 for each penny to general record of modern creation (IIP) and 5 per penny to GDP. GST will acquire immense changes the material business of India. In this examination paper and I have begun with the presentation, as a rule of GST and have attempted to feature the targets the proposed GST is attempting to accomplish. From that point, I have talked about the old backhanded duty administration framework and at that point an exertion has been had to look at the effect on material part under GST administration lastly, the paper makes out a determination.

KEYWORD: GST- Good and Service Tax, Indirect Tax and Textile Sector

\section{INTRODUCTION}

\subsection{GST-An overview: -}

The One Hundred and Twenty Second Amendment Bill of the Constitution of India, formally alluded to as The Constitution (One Hundred and First Amendment) Act, 2016, presented a national Goods and Services Tax in India from 1 July 2017. The GST law is probably going to change the entire situation of current aberrant expense framework. It is considered as greatest assessment change since 1947.Here is a concise order plotting the real points of reference on the proposition for presentation of GST in India:

In 2000, Vajpayee government began discourse on GST by setting up a specialist board Headed by Asim Dasgupta, previous West Bengal back Minister. In 2003, the Kelkar Task Force on backhanded assessment had proposed to have a far reaching backhanded assessment change through GST.

> In 2006, UPA back clergyman P Chidambaram proposes GST in his Union spending plan. The

Engaged panel of state back clergymen was relegated the obligation to chalk out a guide for its execution. 
$>$ In 2008, Empowered board presents a report 'A model and guide for GST in India'.

$>$ Based on contributions from the Centres and expresses, the engaged advisory group discharged its first exchange paper on GST in November, 2009. Keeping in mind the end goal to change the Constitution to empower presentation of GST, the Constitution (115th Amendment) Bill was presented in the Lok Sabha in March 2011.

$>$ According to the endorsed method, the Bill was alluded to the Standing Committee on Finance of Parliament for examination and report.

$>$ The Parliamentary Standing Committee presented its report in August, 2013, to the Lok Sabha. The greater part of the proposals made by the Empowered Committee furthermore, the Parliamentary Standing Committee was acknowledged and the draft Amendment Bill was reasonably overhauled.

$>$ In June 2014, the draft Constitutional Amendment Bill was sent to the Empowered Committee after endorsement of the new government.

$>$ In 2015, Jaitely in his spending discourse sets GST rollout due date on April1, 2016. Lok sabha favors the bill on may6. The congress requests topping GST rate at $18 \%$. The NDA government neglects to get it go in Rajya Sabha.

$>$ In 2016, focus and states concede to constitution revision charge without a top on the rates. The bill is endorsed by the RS on august 2016 . The revised bill is passed in the LS on august8.

$>$ The GST committee headed by the Union Finance is framed. The board settled on four-chunk rate GST structure of $5 \%, 12 \%, 18 \%$ and $28 \%$. The 'wrongdoing' or 'bad mark' items, for example, tobacco things, circulated air through beverages what's more, extravagance autos, would go under the most noteworthy duty chunk what's more, may pull in a cess, which would raise the expense weight to $40 \%$.

$>$ In 2017, the date for the execution of the new expense structure is moved July 1, 2017, as the inside and states set aside opportunity to finish the draft charges CGST, IGST, SGST furthermore, UGST.

Indian government has taken the biggest step in taxation reform and is all set to integrate state economy and boast overall growth.

\subsection{Classification of textile industry:-}

Textile industry is classified into two categories, organized mill sector and decentralized sector. In organized category there is cotton mill, both spinning and composite, and in non cotton mill, both spinning and weaving unit and a large number of processing houses. Wherein decentralized sector there is handloom and power loom producing variety of products in different parts of the country.

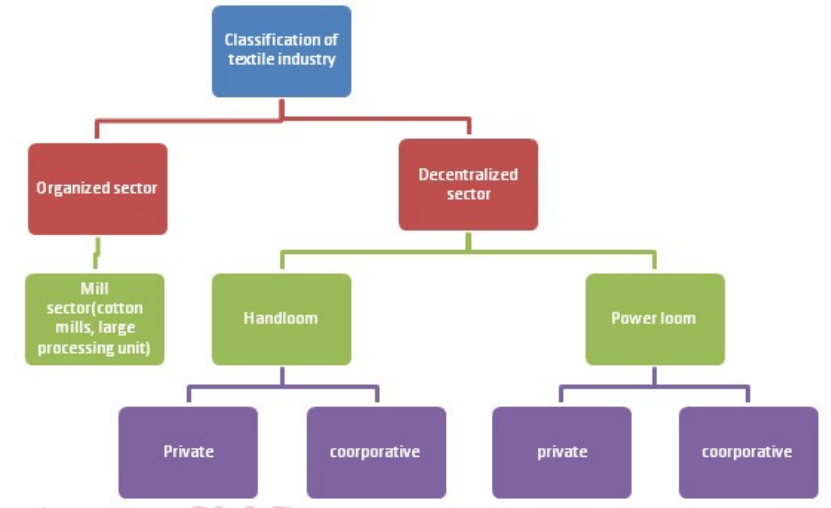

a) Mill sector-

The cotton textile industry is the largest single organized industry in the country which employees about 12 lakh people. Other than there are a substantial number of subordinate businesses relying on this segment. On the presumption that a labor's family involves five people, the immediate reliance on the sorted out material industry works out to around 60 lakhs. The cotton process industry saw a quick development of spinning side amid the most recent six decades. The quantity of units in the industry went up from 107 to 1565 while spindle age expanded from 11.25 million to 35.53 million. The development of loom age has be that as it may been irrelevant by virtue of the stop forced by Government policy to secure the handloom.

\section{b) Handlooms-}

The handloom sector is the second largest unorganized economic activity after agriculture and gives the most extreme work in the country regions, besides farming. The number of handlooms in the nation has step by step gone up from around 28 lakhs in 1951 to around 38.91 lakhs in 2001-2002. A dominant part of these handlooms chip away at cotton, while a hardly any additionally used other crude materials like silk, fleece, craftsmanship silk and other man made filaments. The generation of the cotton material by the handloom segment has expanded from a level of around 1240 million meters in 1951 to 8049 million meters in 2001-2002. The handloom segment moreover produces textures yet no dependable figures of these are accessible. 
The handloom segment mostly delivers dhoties, sarees, lungies, towels, bed sheets and outfitting materials.

\section{c) Power loom-}

The power loom division is of comparatively ongoing birthplace. Since the 50's the limit of power loom part expanded generously year after year. Due to operational points of interest appreciated by the power loom segment in contrast with the plant area and mostly in light of money related concessions the creation limit in the power loom segment expanded generously and therefore the Government needed to continue regularizing the power looms every now and then. To start with power loom was introduced in Ichalkaranji in Maharashtra. The area relies on the plant segment for its supply of yam, chiefly in the shape of canes and shafts. The majority of the power loom proprietors are little scale administrators, who rely on the ace weavers or shippers who give them yam on credit and buy the dim textures by paying them transformation cost. Their little power loom weavers are not business person in their own particular right be that as it may, are just converters. The ace weavers or dealers get the textures prepared and offer them in the market.

\section{Evolution and Development of Textile Industry-}

The term 'Textile' is a Latin word originating from the word 'texere' which means 'to weave'. Textile refers to a flexible material comprising of a network of natural or artificial fibres, known as yarn. Textiles are formed by weaving, knitting, crocheting, knotting and pressing fibres together. The history of textile is almost as old as that of human civilization and as time moves on the history of textile has further enriched itself. In the 6th and 7th century BC, the oldest recorded indication of using fibre comes with the invention of flax and wool fabric at the excavation of Swiss lake inhabitants. In India the culture of silk was introduced in 400AD, while spinning of cotton traces back to $3000 \mathrm{BC}$. In China, the discovery and consequent development of sericulture and spin silk methods got initiated at 2640 BC while in Egypt the art of spinning linen and weaving developed in 3400 BC. The discovery of machines and their widespread application in processing natural fibres was a direct outcome of the industrial revolution of the 18th and 19 th centuries. The discoveries of various synthetic fibers like nylon created a wider market for textile products and gradually led to the invention of new and improved sources of natural fibre. The development of transportation and communication facilities facilitates the stream of ITC. On the off chance that an enrolled citizen obtains the contribution from citizens under the synthesis plot or the sloppy part, ITC won't be took into account him. Presently with the usage of GST, the information credit framework easily moves the adjust toward the composed part.

\section{Fundamental Concept of Gst on Textile- \\ 3.1 Impact of GST on textile industry:-}

In spite of a few changes under the GST administration, the textile sector is in for specific impact with the execution of the GST. The tax administration will affect the textile business by acquiring following changes.

\section{Introducing a break in input credit chain}

As an extensive lump of the textile industry in the nation works under the disorderly segment or the piece plot, consequently making a gap between the flows of ITC.

\section{Reduction in manufacturing cost}

By subsuming the other taxes, for example, the sections impose, extravagance charge, Octroi, and so on. The expenses for the producers will be diminished in the textile sector.

\section{Allowing input credit on capital good}

The cost of import of securing the most recent innovation to fabricate material merchandise is costly in light of the fact that the extract obligation paid for the same isn't permitted at ITC. Under GST, in any case, ITC will be accessible for all the assessment paid on capital products.

\section{Increase in export of textile product}

The process of asserting ITC is streamlined because of GST which enables the material segment to be focused in the fare showcase. Because of the broad cost of the technique and postpones made during the time spent obligation downside, a considerable measure of producers and dealers were not slanted towards trade amid the pre-GST administration. Under the GST regime, the obligation downside framework has lost its importance, and information charge acknowledges will be given as discount rather than the obligation disadvantage plans. This is an essential lift that was required for advancing the fare of material items. 
Despite the fact that there are a couple of detriments of the GST on the material business, it is protected to state that it will help the part over the long haul. It will get numerous enlisted citizens under a very much looked after framework. It can likewise be said that the new expense administration will enable the material business to extend itself in both the residential and additionally worldwide markets in this manner making feasible and long haul development openings.

\subsection{Contribution of textile industry in GDP of Indian economy:-}

In the previous one year, there has been a massive upsurge in the material business of India. The business measure has extended from USD 37 billion out of 2004-05 to USD 49 billion of every 2006-07. Amid this time, the nearby market saw a development of USD 7 billion, that is, from USD 23 billion to USD 30 billion. The fare showcase expanded from USD 14 billion to USD 19 billion in a similar period.

The material business is one of the main areas in the Indian economy as it contributes about 14 percent to the aggregate modern generation. The material business in India is guaranteed to be the greatest income workers as far as outside trade among all other mechanical segments in India. This industry gives guide work to around 35 million individuals, which has made it a standout amongst the most worthwhile mechanical divisions in the nation.

A portion of the essential advantages offered by the Indian material industry are as per the following:

$>$ India covers 61 percent of the universal material market.

$>$ India covers 22 percent of the worldwide market.

$>$ India is known to be the third biggest maker of cotton over the globe.

$>$ India cases to be the second biggest maker and in addition supplier of cotton yarn and materials on the planet.

$>$ India holds around 25 percent share in the cotton yarn industry over the globe.

$>$ India adds to around 12 percent of the world's generation of cotton yarn and materials.
Following are the measurements computed according to the commitment of the parts in Textile industry in India GDP:

$>$ India holds 22 percent share in the material market in Europe and 43 percent share in the clothing business sector of the nation. USA holds 10 percent and 32.6 percent partakes in Indian materials and clothing.

$>$ Barely any other worldwide nations separated from USA and Europe, where India has a checked nearness incorporate UAE, Saudi Arabia, Canada, Bangladesh, China, Turkey and Japan.

Instant pieces of clothing represents 45 percent share holding in the aggregate material fares and 8.2 percent in trade generation of India

Fare creation of floor coverings has seen a noteworthy development of 42.23 percent, which obviously remains at USD 654.32 million amid 2004-05 to USD 930.69 million in the year 200607 . India holds 36 percent share in the worldwide material market as has been assessed amid AprilOctober 2007

The specialized materials advertise in India is accepted to contact USD 10.63 billion by $2007-08$ from USD 5.09 billion amid 2005-06, which is around twofold. It is additionally accepted to contact USD 19.76 billion continuously 2014-15

By 2010, India is relied upon to twofold its offer in the worldwide specialized material market.

$>$ The whole division of specialized materials is assessed to achieve USD 29 billion during 20052010.

\section{INDIRECT TAXES APPLIED IN TEXTILE INDUSTRY-}

Present indirect taxes applied for the Industry:-

\section{Central Excise Duty-}

Central Excise Duty was first demanded on woven articles of clothing in 2001. In this manner the entire material Industry was brought under the Excise Duty net by 2003. A possibility for availment of exception from instalment of Excise Duty was presented vides Notification no.30/2004 with a condition that any maker profiting the choice isn't qualified for CENVAT credit on information sources and information administrations. There was likewise a choice to pay concessional rate of extract obligation with Cenvat credit advantage. A large portion of the producers in the Textile Industry decided on exception. 


\section{VAT/ Sales tax-}

The vast majority of the states in India have exempted materials and textures from impose of VAT/deals assess. Wherever no exception has been given, for little players, the choice of paying charges at concessional rates is additionally given under organization plot in numerous states.

\section{Entry Tax-}

In numerous states, passage imposes is collected on determined products when such merchandise enter neighbourhood. Indeed, even materials, for example, cotton, woolen or silk or counterfeit silks are at risk to passage charge in states like Karnataka at the rate of $1 \%$ which is adding to buy cost.

\section{Custom Duty-}

Custom duty in India is delineated under the custom Act, 1962 and grants the administration to demand levy duty on fares and imports, disallow fare and import of merchandise, methodology for bringing in/sending out and offenses, punishments and so forth. Under traditions obligation diverse expenses are required like Basic traditions Duty, Additional Customs Duty (CVD), Protecting obligation, Antidumping obligation and Safeguard obligation.

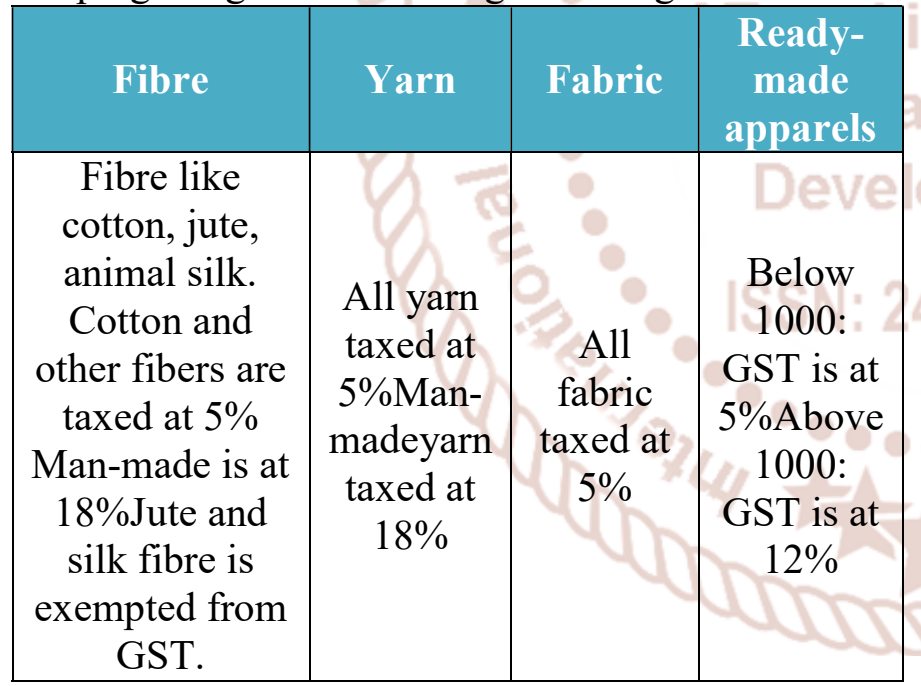

\section{TYPES OF TEXTILE INDUSTRY IN INDIA-}

Textile Industry is divided into various sorts. They are listed below:

\begin{tabular}{ll}
$>$ & Cotton textile \\
$>$ & Jute and coir textile \\
$>$ & Woolen textile \\
$>$ & Silk textile \\
$>$ & Readymade garments \\
\hline
\end{tabular}

India Textile industry is one of the leading in the world. Right now it is assessed to be around US\$ 52 billion and is additionally anticipated to be around US\$ 115 billion continuously 2012. The present residential market of material in India is required to be expanded to US\$ 60 billion by 2012 from the current US\$ 34.6 billion. The material fare of the nation was around US\$ 19.14 billion out of 2006-07, which saw a firm ascent to achieve US\$22.13 out of 2007-08. The offer of fares is likewise anticipated that would increment from 4\% to $7 \%$ inside 2012 .

\section{CASE STUDY-VARDHMAN TEXTILE \\ 6.1 Introduction: -}

Vardhman Group is a textile industry situated in Ludhiana, Hoshiarpur, Perundurai(Tamil Nadu), Baddi(Himachal Pradesh), and Vizag(A.P) along with 20 distribution centre. Vardhman Group was set up in 1965 by Lala Rattan Chand Oswal. The gathering is occupied with assembling and exchanging Yarn, Greige and Processed Fabric, Sewing Thread, Acrylic fibre and Alloy steel. Vardhman aggregate was joined in 1962 as Vardhman Spinning and General Mills (VSGML). The organization was advanced by VS Oswal and RC Oswal at first and is currently headed by S. P. Oswal. The aggregate number of workers in the organization as of April 2011 is 23000.

\subsection{Product: -}

A product of the Vardhman textile are: simple and mixed yarns, acrylic fibre, scope of strings (clothing sewing, tea packs, modern strings, and so forth.), shirting and pant materials, producing and car parts and steel.

\subsection{Export history:-}

The organization began sending out from 1990- 91 and it trades basically to Spain, UK, Germany, US, Japan and some African and E. Asian nations. Fares represent $22 \%$ of the gathering's incomes.

\subsection{History of Vardhman yarns:-}

Thread division starts operation- 1982

Licensee agreement with A\&E (American and Efird LLC) -2001

Joint Venture with A\&E- 2008

\subsection{Effect of GST in Vardh man yarn: -}

Good and service tax also affected yarn. The GST rate is increased by $5 \%$. The rate of Vardh man kitten yarn box which contain 6 pieces was 330, but after the implementation of GST the price changed and the current M.R.P price for vardh man kitten yarn is 350 . 


\section{CONCLUSION-}

From above discussion it is inferred that presentation of GST will introduce a plenty of changes in the material business of India with a general positive effect on the segment. GST execution is required to deliver force to different changes and arrangement measures conceived by the Government for the simplicity of working together and to usher India into a straightforward, straightforward and charge well disposed administration. It will rearrange the present methodology by merging different complex aberrant expenses into a bound together stage and conjointly enhance the "material fare" situation of India.

The consistent would see their products wind up aggressive and the division would conjointly partake in adding to charge in expansion to giving business and other social advantages at a level higher than today's. Presumably that GST will give India a world class charge framework by amalgamating recent totally extraordinary medications to assembling and benefit part. Be that as it may, this will be liable to its balanced style, convenient execution and customary development. Henceforth, it can be reasoned that GST in the Indian structure will connect income spillages to current framework and at the same time will give help to citizen as far as lessened duty trouble, end of falling impact and consistent stream of input credit on the vast majority of the items, notwithstanding releasing a flood of business benefits up to this point immaculate by the VAT framework and would basically prompt Monetary Development.

\section{REFRENCE}

1. http://www.thehindu.com/business/Economy/now -ser-

Vice-tax-regime-comes-into-effect Sunday/article3589492.ece

from-

2. http://www.thehindu.com/business/Industry/agricu lture-commodity-prices-to-rise-postgstkelkar/article5007105.ece

3. http://www.thehindu.com/business/Industry/cabin et-nod-for-amended-bill/article6701784.ece

4. http;//www,thehindu.com/business/Industry/gsthas-a-good-probability-in-tax-horizonparthasarthishome/article453507.ece

5. http://www.thehindu.com/business/Industry/gstwill-benefit-food-processingindustrypawar/article5478407.ece 